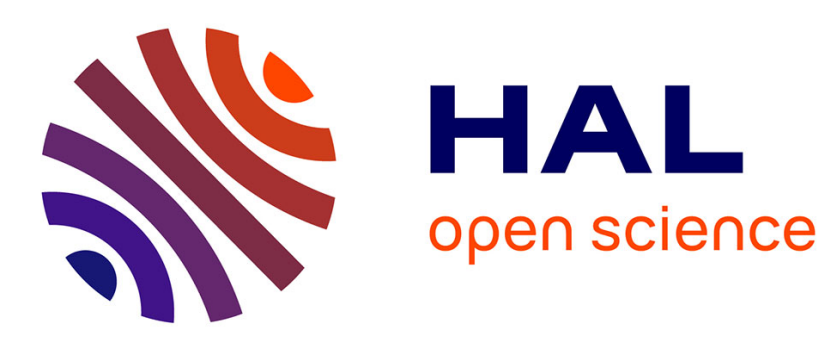

\title{
Down with Covid: Patterns of Electoral Turnout in the 2020 French Local Elections
}

\author{
Tristan Haute, Camille Kelbel, François Briatte, Giulia Sandri
}

\section{To cite this version:}

Tristan Haute, Camille Kelbel, François Briatte, Giulia Sandri. Down with Covid: Patterns of Electoral Turnout in the 2020 French Local Elections. Journal of Elections, Public Opinion and Parties, 2021, 31 (sup1), pp.69-81. 10.1080/17457289.2021.1924752 . halshs-03284356

\section{HAL Id: halshs-03284356 \\ https://shs.hal.science/halshs-03284356}

Submitted on 23 Sep 2021

HAL is a multi-disciplinary open access archive for the deposit and dissemination of scientific research documents, whether they are published or not. The documents may come from teaching and research institutions in France or abroad, or from public or private research centers.
L'archive ouverte pluridisciplinaire HAL, est destinée au dépôt et à la diffusion de documents scientifiques de niveau recherche, publiés ou non, émanant des établissements d'enseignement et de recherche français ou étrangers, des laboratoires publics ou privés. 
Down with Covid: patterns of electoral turnout in the 2020 French local elections

Tristan Haute ${ }^{1}$, Camille Kelbel, François Briatte and Giulia Sandri ${ }^{2}$

To cite this article: Tristan Haute, Camille Kelbel, François Briatte \& Giulia Sandri (2021), Down with Covid: patterns of electoral turnout in the 2020 French local elections, Journal of Elections, Public Opinion and Parties, 31 (1), 69-81., DOI: 10.1080/17457289.2021.1924752

\begin{abstract}
This article contributes to the ongoing research effort assessing the effects of the COVID-19 crisis on turnout in the municipal elections held in France in March and June 2020. Holding the election in pandemic times caused turnout to drop significantly, but unevenly so across the electorate. We use both aggregate electoral results at the polling station level and individual-level data drawn from a survey we conducted between June and July $2020^{3}$. If fear of contagion partly explains voters' abstention, this article highlights the contradictory effects of the pandemic on the socioeconomic determinants of voter turnout. On the one hand, the variation in turnout levels by age, which usually is quite significant in France, has considerably decreased in 2020. On the other hand, the differences in turnout levels according to the voters' economic and social status have been reinforced during the pandemic. This analysis of local individual data shows that the health crisis has generated important consequences also on the patterns of social inequalities in political representation.
\end{abstract}

KEYWORDS: COVID-19; voting; local elections; socioeconomic variables; France

CONTACT: Giulia Sandri, giulia.sandri@univ-catholille.fr, European School of Political and Social Sciences (ESPOL), Université Catholique de Lille, 60 boulevard Vauban - CS 4010, Lille F-59016, France

Acknowledgements

We thank Marie Neihouser and Felix-Christopher von Nostitz (Université Catholique de Lille, ESPOL) for their contribution to the PELMEL survey, as well as Cécile Rodrigues and Thomas Soubiran (CNRS, CERAPS) for providing geographic data used in our analysis. We also thank the CRÉMI (Collectif de Recherche sur les Élections Municipales et Intercommunales) for inspiring us to work on this topic.

Funding

This work was supported by the Lille Center for European Research on Administration, Politics and Society (CERAPS, Université de Lille / CNRS / Sciences Po Lille), and by the European School of Political and Social Sciences (ESPOL, Université Catholique de Lille).

\footnotetext{
${ }^{1}$ Université de Picardie Jules Verne, CNRS, UMR 7319, CURAPP-ESS, Amiens, France / Université de Lille, CNRS, UMR 8026, CERAPS, Lille, France

${ }^{2}$ European School of Political and Social Sciences (ESPOL), Université Catholique de Lille, Lille, France

${ }^{3}$ The authors can provide data and $\mathrm{R}$ code to fully replicate the analysis reported in this paper.
} 
Introduction

The COVID-19 pandemic has caused the rescheduling of elections in many political systems. However, while 71 countries across the world decided to postpone national or subnational elections between February and August 2020, at least 60 other countries have held elections in the same period $^{4}$. This unprecedented event offers an interesting setting for measuring the impact of a global public health crisis on voting behavior. Recent and preliminary studies have started exploiting that opportunity, and have shown that the pandemic has caused either a rally-round-the-flag effect, with massive electoral support for incumbents (Leininger and Schaub 2020; Neihouser, Kelbel, and Briatte 2020), or massive abstention (Brouard and McAvay 2020).

In France, the first round of the municipal elections was maintained on March 15 despite the start of strict confinement measures a few days earlier. Only $44.7 \%$ of registered voters went to the polls compared to $63.6 \%$ in 2014 , allowing to designate in that first round 30,125 mayors (out of 34,968). The next day, the government proclaimed the general lockdown and decided to postpone the second round of the elections, which only took place in late June. Turnout then only reached $41.6 \%$ in the remaining 4,843 communes while the average turnout rate in the second round in 2014 was of $62.1 \%$. This drop in turnout in 2020, although impressive, is also part of a continuous decline of turnout in local elections in France, that started in 1989 (Jaffré 2020) with 2014 already marking a historically low point before.

This situation creates both an unprecedented context and a quasi-experimental setting for testing the impact of crises on electoral turnout, a topic on which we know relatively and comparatively little. If health crises cause a decrease in electoral turnout, what about the other determinants of turnout that are generally pointed out to explain such declines?

The overarching theoretical issue raised by the COVID-19 context is whether we should expect (different types of) crises to have any sort of effect on turnout. In a rational choice perspective, there are little incentives to go to the polls as individual voters have only marginal effects on the results (Blais 2000). Thus, adding a further obstacle - or, to stick to the vocabulary, increasing the cost of voting (since going to the polls under a pandemic is likely to be seen as more risky, uncertain, or simply more complicated) - should lead to a decreased turnout.

Drawing more on the tradition of the social-psychological models of political engagement, some have objected that difficult times are propitious for a surge of the sense of civic duty (Uhlaner 1989). In other words, the main triggers of the vote in terms of resources and motivations, be them their socioeconomic situation, political efficacy, or values and norms (Brady, Verba, and Schlozman 1995), are unlikely to be negatively affected in the short-term, even to the contrary. If such is the case, then external shocks should lead to more turnout at the individual level, but mostly among those that display a more acute sense of civic duty. Along the same lines but somewhat contradictorily, famous empirical studies more specifically focusing on the act of voting have shown that social pressure - i.e. being praised for upholding a social norm - and social contacts (Gerber, Green, and Larimer 2008) are likely to enhance political participation, something potential voters have been arguably less subject to in recent months.

\footnotetext{
${ }^{4}$ IDEA. 2020. "Global overview of COVID-19: Impact on elections.” https://www.idea.int/news-media/ multimedia-reports/global-overview-covid-19-impact-elections.
} 
The current coronavirus sanitary crisis is specific mostly in two respects. At the macro level, it constitutes an external shock. There are only a few empirical actual works linking external events to electoral behavior and more specifically to participation patterns. Some isolated works have studied the impact of natural phenomena such as weather conditions or extreme climate events on turnout. Somewhat unsurprisingly, heavy showers have thus been found to lead to the demobilization of voters (Arnold and Freier 2016), albeit with varying effects depending on the national setting in which they occurred (Persson, Sundell, and Öhrvall 2014) or on sense of civic duty (Knack 1994). In the case of massive floods, however, Bodet and his colleagues (2016) find no effect on voter turnout in their indepth study on the Calgary case. Yet another type of external shock that may shed some light on current events are terrorist attacks. Although vote choices are impacted, especially if elections are held closely after, their punctual nature has seemingly made their impact on turnout negligible (Berrebi and Klor 2008, 289-290).

At the micro level, however, the current crisis may have a direct impact especially since it touches upon health. We know little about health and voting, except perhaps precisely that at the individual level poor health impedes turnout, or at least motivation to take part (Denny and Doyle 2007; Mattila et al. 2013; Gollust and Rahn 2015; Pacheco and Fletcher 2014), with arguments ranging from the time-consuming nature of taking care of one's own condition to ill people displaying lower levels of political efficacy.

There are few studies to date that have studied the impact of the current health and sanitary crisis upon elections and they have produced mixed results. In the case of France, some, however, have observed that the higher the turnout in a municipality, the greater the excess mortality due to COVID19 (Bertoli, Guichard, and Marchetta 2020). Along the same lines, Zeitoun et al. (2020) have shown that the greater the risk of epidemics on the territory of a municipality, the lower the abstention. By contrast, basing their analysis on the first round and data collected at the aggregate level on almost 10,000 municipalities, Brouard and McAvay (2020) evidenced that the more a department is affected by the COVID-19 pandemic, the more abstention has increased compared to the 2014 elections (based on several different public health indicators that they use as a proxy for the perceived risk). Similar results are drawn by Noury et al. (2021).

Likewise, according to the survey conducted at the local level we used in this article, a significant proportion of voters ( $42.1 \%$ in the first round, $35.9 \%$ in the second round) declared that they would not have abstained if the health crisis had not taken place. The health dimension alone is however insufficient to explain the overall low levels of turnout and in particular its decline between the first and the second round. The Brouard and McAvay study (2020) carries several specific insights on this issue. On the one hand, it shows that higher proportions of older voters (over 65 years of age) in a municipality led to lower turnout rates in 2020 compared to their 2014 levels. On the other hand, the sociodemographic characteristics of the municipalities are associated with significant variations in abstention; the more the proportion of high school graduates has increased, the less abstention followed a similar path.

More generally, previous studies on the relationships between voter turnout and traditional sociodemographic variables (gender, age, socio-professional category, level of education) have concluded until recently that higher shares of abstainers are to be found in the ranks of the youngest voters or the members of the working class. This is especially true of France, where the so-called "heavy variables" or main socioeconomic features of the electorate (age, education level and socio- 
professional situation) have almost invariably been found to preserve their discriminatory power in determining turnout (Braconnier, Coulmont, and Dormagen 2017).

Overall, this article examines the social determinants of electoral turnout in times of crisis. Based on the case of the 2020 municipal elections in France and comparing the profile of voters with other ballots, we consider whether the drop in turnout, which we assume to be largely related to the health crisis, is affecting all voters in the same way. In other words, have social inequalities in electoral participation, which are highly prevalent in France, been maintained, reduced or reinforced under the effect of the health crisis?

Materials and methods

This article combines data both at aggregate (electoral results at the polling station level) and at individual levels (original survey data) on a specific case study, namely the metropolitan area of Lille, which is composed of 95 different municipalities and which represents as such the fourth largest French city $(1,146,320$ inhabitants in 2017). The case study is selected because of its sociodemographic characteristics: the metropolitan area is mostly urban, with high population density, and is structured by strong social inequalities (Collectif Degeyter 2017) which traditionally affect political dynamics, especially at the electoral level (Rivière et al. 2014).

At the aggregate level, we compared the turnout rates at the 2014 and 2020 municipal elections calculated at the level of the 658 polling stations ${ }^{5}$ of the Lille metropolitan area - with demographic data from the electoral listings and with socioeconomic data from the population census (see Table 1).

The comparison between population census data and electoral listings data required a reapportion procedure. We carried it out using the "spReapportion" R package (Gombin 2017), due to the fact that sub-municipal census data are not available at the polling station level, but only at the level of the socalled "IRIS" statistical units (Ilots regroupés pour l'information statistique), a territorial unit of the same order of magnitude. For each election, we then calculated the correlation between turnout rates and several socio-economic variables related to eligible voters and local residents, including age, education attainment and occupational status.

At the individual level, we use original opinion poll data from the "PELMEL" ("Participation ÉLectorale dans la MEtropole Lilloise" - Electoral participation in the Lille metropolitan area) surveys. This survey was carried out online by two research centers (ESPOL and CERAPS) ${ }^{6}$ and a polling institute, Dynata France, based on a sample of 863 respondents, representative of the population of the Lille metropolitan area aged 18 and over. The sample was selected according to age and gender population quotas, and we used the "icarus" R package (Rebecq 2019) to compute poststratification weights in order to match the marginal distribution of the sample to known population margins, using levels of educational attainment and vote choices in the first round of the 2017 presidential election.

To analyze which factors robustly determine electoral behavior in our survey, we estimate two logistic regression models, using voting in the first round of the municipal elections of 2020 and

\footnotetext{
${ }^{5}$ There are 63 additional polling stations whose boundaries were changed between 2014 and 2020 and that are not included in the current analysis.

${ }^{6}$ The research team consists of the authors of this article as well as Marie Neihouser and Felix-Christopher von Nostitz (Université Catholique de Lille, ESPOL).
} 
voting in the first round of the presidential election of 2017 as dependent variables. The predictors included in the models are gender, age, level of education, current or last occupation, and interest in politics (at the local level for the municipal election, at the national level for the presidential election). Figure 1 shows the estimated coefficients of both models, the full results of which are listed in Table 2 along with voting rates per predictor.

Results

Observing the relationships between voter turnout and traditional sociodemographic variables (gender, age, socio-professional category, level of education), and taking into consideration the specificities of French social context, two major results appear in 2020 municipal elections. On the one hand, the participation gaps based on the age of voters have narrowed in 2020 compared to previous elections, although seniors are still among the most active participants. On the other hand, however, differences in turnout according to economic and social status have stayed the same, or even increased, due to the sanitary context.

Comparing the profile of voters reveals a narrowing of participation gaps by age in 2020 (see Table 1). According to our survey, voters aged 18-29 in 2020 who were also eligible to vote in 2017 participated significantly less than their elders in the first round of the presidential election $(65.2 \% \mathrm{vs}$ $78.7 \%$ of all respondents) (Table 2). For the first round of the 2020 municipal election, however, the difference in turnout was smaller and not statistically significant. Nevertheless, the oldest voters -i.e. those aged 45 and over - are still the most likely to participate in any given election.

Similarly, an analysis at the level of polling stations in the Lille metropolitan area (Table 1) reveals that turnout is positively correlated with the average age of voters in a polling station, whether in the first or second round of the 2020 municipal elections ( +0.39 for both rounds). However, this relationship was much stronger in 2014 (coefficients of +0.52 in the first round and +0.59 in the second round). 
Table 1. Correlation matrix of municipal election vote rates and sociodemographic characteristics, Lille metropolitan area.

\begin{tabular}{lllll}
\hline & $\begin{array}{l}\text { \% Vote in } \\
\text { Round 1 in 2020 }\end{array}$ & $\begin{array}{l}\text { \% Vote in } \\
\text { Round 2 in 2020 }\end{array}$ & $\begin{array}{l}\text { \% Vote in } \\
\text { Round 1 in 2014 }\end{array}$ & $\begin{array}{l}\text { \% Vote in } \\
\text { Round 2 in 2014 }\end{array}$ \\
\hline $\begin{array}{l}\text { Mean voter age } \\
\text { \% of university }\end{array}$ & +0.39 & +0.39 & +0.52 & +0.59 \\
graduates & +0.42 & +0.32 & +0.28 & +0.20 \\
$\begin{array}{l}\text { \% with no high } \\
\text { school diploma }\end{array}$ & -0.41 & -0.28 & -0.31 & +0.17 \\
\% of managers & +0.40 & & & \\
\% of intermediate & +0.52 & +0.33 & +0.24 & +0.15 \\
professions & & +0.38 & +0.57 & +0.47 \\
\% of self-employed & +0.45 & & & \\
\% of unemployed & -0.63 & +0.36 & +0.41 & +0.42 \\
\% of inactive & -0.49 & -0.60 & -0.75 & -0.74 \\
(nonworking) & & -0.56 & -0.55 & -0.57 \\
\% of homeowners & +0.46 & & & +0.70 \\
\% of social housing & -0.51 & +0.44 & +0.68 & -0.49 \\
tenants & & -0.54 & -0.56 & -0.72 \\
\% of immigrants & -0.61 & & & 359 \\
\hline$N$ (polling stations) & 658 & -0.57 & -0.73 & \\
\hline
\end{tabular}

Note: All Pearson correlation coefficients above at are statistically significant at $\mathrm{p}<0.01$. The unit of analysis is polling station areas located in the Lille metropolitan area as of 1 January 2020. In order to match them with population census data, we only observe polling station areas with identical boundaries in 2014 and 2020. Not all stations are used during the second round, hence the lower sample size for those.

Source: French Ministry of the Interior for the vote rates, electoral listings by the Préfecture du Nord for polling stations, and French Census by INSEE for the sociodemographic data, which are from 2016.

Therefore, while the decline in turnout concerns all age categories, it is more significant among seniors. Some of them, who are more "at risk", may have given up participating for fear of contamination. Nonetheless, inequalities in turnout based on age have not disappeared, as young people remain more marginalized from electoral practice than their elders do. While age-related disparities in turnout narrowed between 2014 and 2020, those related to socioeconomic status appear to have remained constant in 2020, or have even increased.

Comparing the profile of voters between the 2017 presidential election and the 2020 municipal elections may indicate a weakening of social inequalities in turnout. For example, university graduates voted significantly more in the first round of the 2017 presidential election (90.5\%) than all respondents $(78.7 \%)$, a difference not found in the first round of the 2020 municipal elections $(64.3 \%$ vs $60.1 \%$ ). However, if education has often been pointed out as the single most significant factor influencing one's propensity to go to the polls and to participate politically, it should be remembered that, in municipal elections in France, differences in turnout according to socio-professional position or level of education are traditionally smaller than in national elections. This is notably because geographical mobility, which particularly concerns university graduates and managers, does not favor their participation in local elections as shown previously by Héran and Rouault (1995). 
Furthermore, some of the social groups with relatively lower participation in the 2017 presidential election appear to be still disengaged from the voting process in the first round of the 2020 elections. This is the case for people whose current or last employment contract was non-permanent: only $55.1 \%$ of them voted in the first round of the 2020 municipal elections compared to $60.1 \%$ of all respondents. The same is true for respondents who have never worked, with only $27.7 \%$ of them having voted in the first round of the 2020 municipal elections (see Table 2). These results confirm that socioeconomic status strongly affects political participation in general and electoral participation in particular.

Figure 1. Comparison of log-odds of voting in the municipal (2020) and presidential (2017) elections.

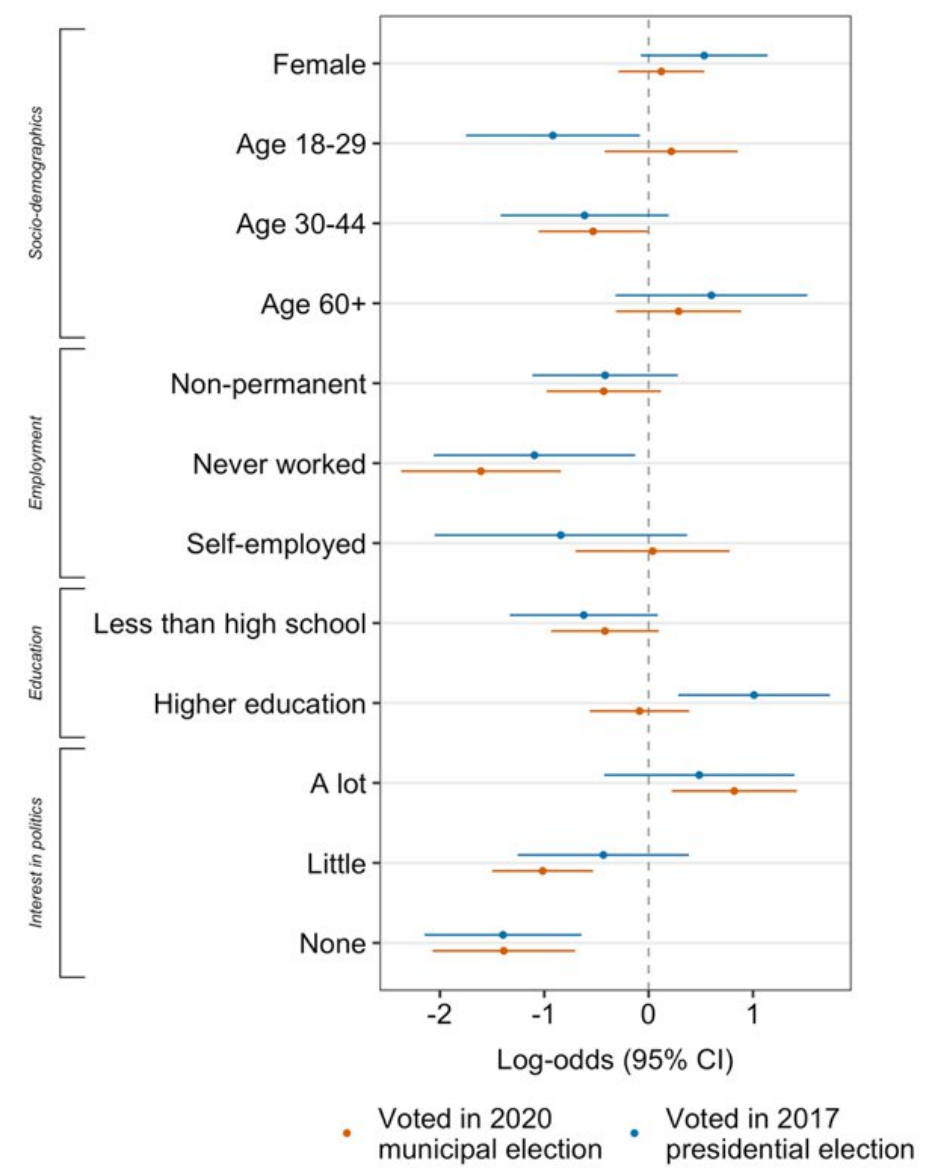

Note: Point estimates show the log-odds of the models summarized in Table 2, with 95\% confidence intervals. Baseline categories are being male, aged 45-59, with high school education, on permanent employment, with some interest in either local or national politics, for the municipal and presidential models respectively. Source: PELMEL survey, 2020. 
Table 2. Survey-weighted logistic regression models of voting in the municipal (2020) and presidential (2017) elections

\begin{tabular}{|c|c|c|c|c|c|c|c|}
\hline Variable & & \multirow{2}{*}{$\begin{array}{l}\% \text { Voted in } \\
\text { municipal } \\
\text { election } \\
2020 \text {, } \\
\text { Round } 1 \\
60.1\end{array}$} & \multirow[t]{2}{*}{$\begin{array}{l}\text { Log- } \\
\text { odds } \\
\text { (SE) }\end{array}$} & \multirow[t]{2}{*}{$\begin{array}{l}\text { Odds } \\
\text { ratio }\end{array}$} & \multirow[t]{2}{*}{$\begin{array}{l}\% \text { Voted in } \\
\text { presidential } \\
\text { election } \\
2017, \\
\text { Round } 1 \\
78.7\end{array}$} & \multirow[t]{2}{*}{$\begin{array}{l}\text { Log-odds } \\
\text { (SE) }\end{array}$} & \multirow[t]{2}{*}{$\begin{array}{l}\text { Odds } \\
\text { ratio }\end{array}$} \\
\hline & $\begin{array}{l}\text { (Full } \\
\text { sample) }\end{array}$ & & & & & & \\
\hline \multirow{2}{*}{ Gender } & Male & 60.7 & ref & ref & 77.0 & ref & ref \\
\hline & Female & 59.5 & $\begin{array}{l}0.12 \\
(0.21)\end{array}$ & 1.13 & 80.0 & $\begin{array}{l}0.53 \\
(0.31)\end{array}$ & 1.70 \\
\hline \multirow[t]{4}{*}{ Age } & $18-29$ & 53.8 & $\begin{array}{l}0.22 \\
(0.33)\end{array}$ & 1.24 & 65.2 & $\begin{array}{l}-0.92 * \\
(0.43)\end{array}$ & $0.40^{*}$ \\
\hline & $30-44$ & 51.1 & $-0.53 *$ & $0.59^{*}$ & 74.7 & $\begin{array}{l}-0.61 \\
(0.41)\end{array}$ & 0.54 \\
\hline & $45-59$ & 62.7 & ref & ref & 80.6 & ref & Ref \\
\hline & $60+$ & 69.1 & $\begin{array}{l}0.29 \\
(0.31)\end{array}$ & 1.33 & 86.6 & $\begin{array}{l}0.60 \\
(0.47)\end{array}$ & 1.82 \\
\hline \multirow[t]{3}{*}{$\begin{array}{l}\text { Educational } \\
\text { attainment }\end{array}$} & $\begin{array}{l}\text { Less than } \\
\text { high school }\end{array}$ & 56.9 & $\begin{array}{l}-0.24 \\
(0.26)\end{array}$ & 0.66 & 70.6 & $\begin{array}{l}-0.62 \\
(0.36)\end{array}$ & 0.54 \\
\hline & High school & 59.6 & ref & ref & 77.5 & Ref & Ref \\
\hline & $\begin{array}{l}\text { Higher } \\
\text { education }\end{array}$ & 64.3 & $\begin{array}{l}-0.09 \\
(0.26)\end{array}$ & 0.92 & 90.5 & $\begin{array}{l}1.01 * * \\
(0.37)\end{array}$ & $2.75^{* *}$ \\
\hline \multirow{4}{*}{$\begin{array}{l}\text { Occupation } \\
\text { (current or } \\
\text { last) }\end{array}$} & Permanent & 65.8 & ref & ref & 84.1 & Ref & Ref \\
\hline & $\begin{array}{l}\text { Non- } \\
\text { permanent }\end{array}$ & 55.1 & $\begin{array}{l}-0.43 \\
(0.28)\end{array}$ & 0.65 & 71.5 & $\begin{array}{l}-0.42 \\
(0.36)\end{array}$ & 0.66 \\
\hline & $\begin{array}{l}\text { Never } \\
\text { worked }\end{array}$ & 27.7 & $\begin{array}{l}-1.61 * \\
* * \\
(0.39)\end{array}$ & $\begin{array}{l}0.20^{* *} \\
*\end{array}$ & 55.5 & $\begin{array}{l}-1.09^{*} \\
(0.49)\end{array}$ & $0.33^{*}$ \\
\hline & $\begin{array}{l}\text { Self- } \\
\text { employed }\end{array}$ & 68.4 & $\begin{array}{l}0.04 \\
(0.38)\end{array}$ & 1.04 & 73.9 & $\begin{array}{l}-0.84 \\
(0.62)\end{array}$ & 0.43 \\
\hline \multirow[t]{4}{*}{$\begin{array}{l}\text { Interest in } \\
\text { politics }\end{array}$} & A lot & 82.5 & $\begin{array}{l}0.82 * * \\
(0.31)\end{array}$ & $2.27 * *$ & 88.7 & $\begin{array}{l}0.49 \\
(0.47)\end{array}$ & 1.62 \\
\hline & Some & 67.8 & ref & Ref & 83.4 & Ref & ref \\
\hline & Little & 44.9 & $\begin{array}{l}-1.02 * \\
* * \\
(0.25)\end{array}$ & $\begin{array}{l}0.36^{* *} \\
*\end{array}$ & 77.7 & $\begin{array}{l}-0.43 \\
(0.42)\end{array}$ & 0.65 \\
\hline & None & 34.2 & $\begin{array}{l}-1.39 * \\
* * \\
(0.35)\end{array}$ & $0.25 * *$ & 53.3 & $\begin{array}{l}-1.40^{* *} \\
(0.38)\end{array}$ & $0.25^{* * *}$ \\
\hline \multicolumn{2}{|l|}{ Constant } & & $\begin{array}{l}1.20 * * \\
* \\
(0.30)\end{array}$ & $\begin{array}{l}3.34 * * \\
*\end{array}$ & & $\begin{array}{l}1.85^{* * *} \\
(0.48)\end{array}$ & $6.39 * * *$ \\
\hline \multirow{3}{*}{\multicolumn{2}{|c|}{$\begin{array}{l}N \text { ( respond } \\
\text { Akaike Info } \\
\text { Criterion } \\
\text { Pseudo- } R^{2}\end{array}$}} & 699 & 699 & & 659 & 659 & \\
\hline & & & 838.48 & & & 604.24 & \\
\hline & & & 0.24 & & & 0.27 & \\
\hline
\end{tabular}

Note: The dependent variable is voting in one of the elections. Baseline categories are marked as "ref". Both models are estimated on survey-weighted observations using the "survey" R package (Lumley 2020), with 
pseudo-R2 statistics computed using the Nagelkerke method (Lumley 2017). Design-based standard errors for the $\log$-odds are shown in brackets. Two-tailed p-values: ${ }^{* *} \mathrm{p}<0.001,{ }^{*} \mathrm{p}<0.01,{ }^{*} \mathrm{p}<0.05$. Source: PELMEL survey, 2020. The "survey" R package fits weighted logistic regression models by maximizing the HorvitzThompson estimator of the population loglikelihood, which means that they do not have a pseudo log-likelihood (Lumley 2020).

Polling station level analyses lead to similar conclusions. In Table 1, the turnout in a polling station is much more correlated to the share of university graduates in 2020 than in $2014(+0.42$ in the first round of $2020 \mathrm{vs}+0.28$ in the first round of 2014) or to the share of managers (coefficients of +0.40 in the first round of $2020 \mathrm{vs}+0.24$ in the first round of 2014). Other relationships appear also to be slightly less important in 2020 than in 2014. However, Table 1 reveals stable relationships over time. For example, whatever the ballot considered, turnout at a polling station is always negatively correlated with the share of unemployed or inactive people, and to that of immigrants or social housing tenants. Conversely, it is always positively correlated with the share of intermediate professions, self-employed workers and homeowners.

At the meso-level, social or group processes may further separate a large part of the population from polling stations. Voting is above all part of collective dynamics - family, professional and interpersonal - and cannot be dissociated from reference groups and since more recently also from social media. It is these more or less diffuse influences that "activate" the civic norm in variable ways in precise contexts. Voting or not voting thus also depends on the state of the collective organization of the social group (or class) and its mobilization (Braconnier and Dormagen 2007).

Finally, an interest in politics, which is known to be socially determined - because those who display a higher level of political interest are more often found among the ranks of the most educated, betteroff citizens - but is a variable in itself, seem to still go hand in hand with greater electoral mobilization. Respondents who were very interested or somewhat interested in politics overwhelmingly voted in the first round of the 2020 municipal elections ( $82.5 \%$ and $67.8 \%$ respectively), as they did in the first round of the 2017 presidential elections $(88.7 \%$ and $83.4 \%$ respectively). Conversely, the majority of those not at all interested in politics remained on the sidelines in both 2020 (34.2\%) and 2017 (53.3\%). Finally, in 2020, individuals with little interest in politics were barely more mobilized than those with no interest at all (44.9\% vs $34.2 \%)$, while in 2017 they were almost as mobilized as individuals with a fair interest in politics $(77.7 \%$ vs $83.4 \%$ ) (see Table 2). The public health crisis therefore primarily demobilized the citizens least interested in politics, and this holds even if one controls for various other socio-economic factors, as reflected in the predicted probabilities shown in Figures 2 and 3. 
Figure 2. Predicted probabilities of voting in municipal elections (2020) by age, education, and interest in politics.

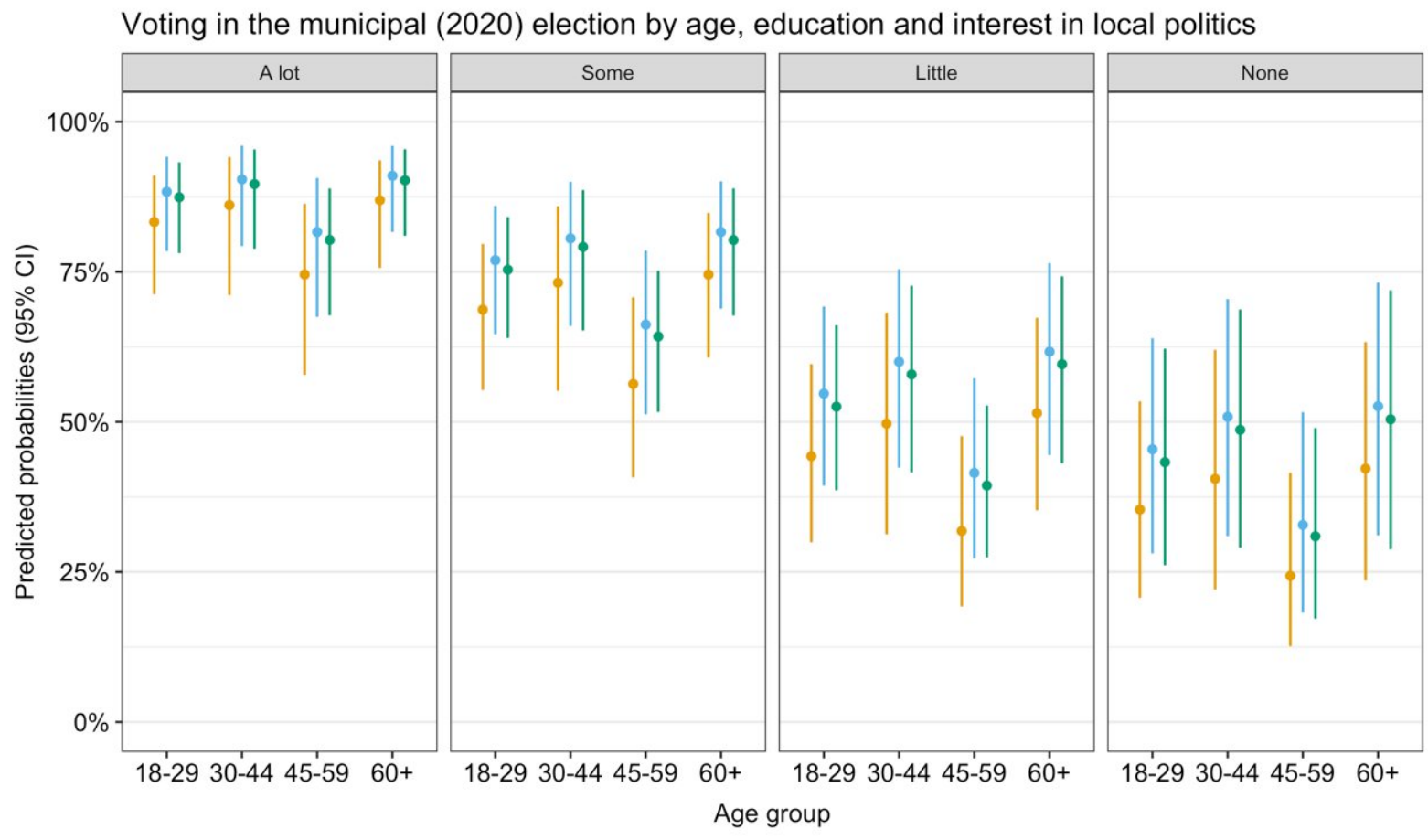

Education $\rightarrow$ Less than high school $\rightarrow$ High school $\rightarrow$ Higher education

Note: Point estimates show the predicted probabilities of the models summarized in Table 2, with 95\% confidence intervals. The main facets of each plot show the varying effects of (from left to right, decreasing) interest in politics. Source: PELMEL survey, 2020. 
Figure 3. Predicted probabilities of voting in presidential (2017) election by age, education and interest in politics.

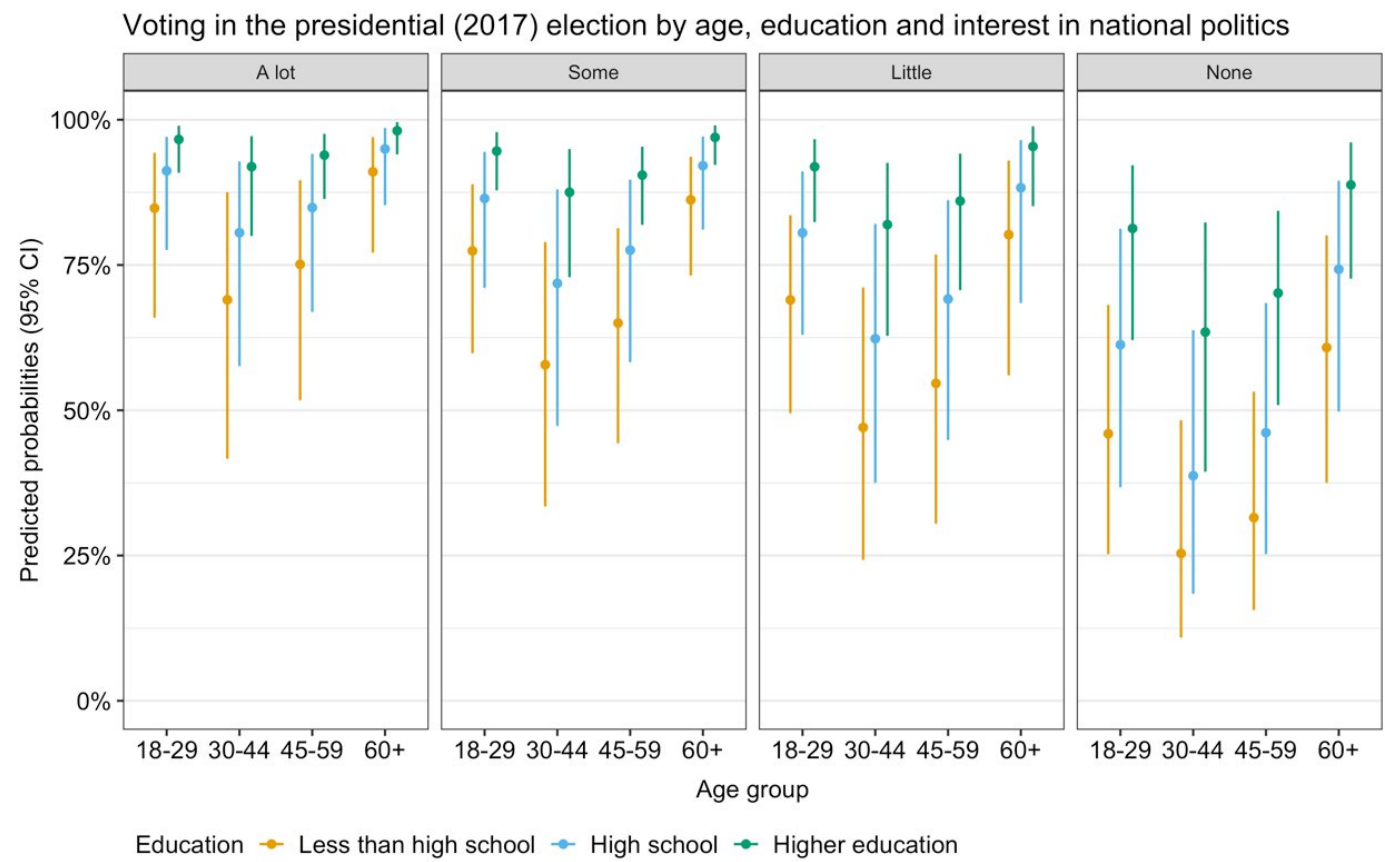

Note: Point estimates show the predicted probabilities of the models summarized in Table 2, with $95 \%$ confidence intervals. The main facets of each plot show the varying effects of (from left to right, decreasing) interest in politics. Source: PELMEL survey, 2020. 


\section{Discussion}

The COVID-19 pandemic had a major impact on the ballots held during the ensuing health crisis. In France, it contributed to an increase in abstention between the 2014 and 2020 municipal elections. Above all, it also had an impact on the inequalities traditionally observed in terms of turnout. In particular, the 2020 municipal elections saw a narrowing of the participation gap according to the age of voters, probably due to the higher mortality risk associated with COVID-19 among the elderly.

However, the age-related differences in voter turnout did not entirely disappear. This suggests that abstention is a phenomenon determined by a multiplicity of factors. Moreover, these elections also saw a worsening of inequalities in turnout by social and economic status, while interest in politics remains a highly predictive variable. Our results seem thus to confirm previous findings showing that, in case of natural events, the ensuing electoral demobilization affects voters differently according to both their sense of civic duty and their partisan preference, which is itself very much socially situated - even though these relationships are not verified in all national contexts.

Considering abstention is a necessary prerequisite for any analysis of election results and the impact of COVID-19 on these. Indeed, both the massive level of abstention and the possible changes in its characteristics, which are highly dependent on local contexts and particularly on the spread of the virus during the first round, have undeniably impacted electoral outcomes. The low level of mobilization may have favored the re-election of well-established outgoing teams, while the greater than usual demobilization of voters least interested in politics and belonging to disadvantaged social groups may have eroded the performance of certain parties, both on the far right and on the left. 
References

Arnold, F., and R. Freier. 2016. "Only Conservatives are Voting in the Rain: Evidence from German Local and State Elections.” Electoral Studies 41: 216-224. doi:10. 1016/j.electstud.2015.10.009.

Berrebi, C., and E. F. Klor. 2008. "Are Voters Sensitive to Terrorism? Direct Evidence from the Israeli Electorate.” American Political Science Review 102 (3): 279-301. doi:10.1017/S0003055408080246.

Bertoli, S., L. Guichard, and F. Marchetta. 2020. "Turnout in the Municipal Elections of March 2020 and Excess Mortality During the COVID-19 Epidemic in France.” IZA Discussion Paper Series No. 13335. June. https://www.iza.org/publications/dp/ 13335/turnout-in-the-municipal-elections-ofmarch-2020-and-excess-mortality-during-the-covid-19-epidemic-in-france.

Blais, A. 2000. To Vote or Not to Vote: The Merits and Limits of Rational Choice Theory. Pittsburgh: University of Pittsburgh Press.

Bodet, M. A., M. Thomas, and C. Tessier. 2016. "Come Hell or High Water: An Investigation of the Effects of a Natural Disaster on a Local Election.” Electoral Studies 43: 85-94. doi:10.1016/j.electstud.2016.06.003.

Braconnier, C., B. Coulmont, and J.-Y. Dormagen. 2017. "The Heavy Variables Are Still Alive and Kicking. The Drop in Voter Turnout and the Increase in Electoral Disparities in Spring 2017.” Revue Française de Science Politique 67 (6): 1023-1040. doi:10.3917/rfsp.676.1023.

Braconnier, C., and J.-Y. Dormagen. 2007. La démocratie de l'abstention. Paris: Gallimard.

Brady, H. E., S. Verba, and K. L. Schlozman. 1995. "Beyond SES: A Resource Model of Political Participation.” American Political Science Review 89 (2): 271-294. doi:10. 2307/2082425.

Brouard, S., and H. McAvay. 2020. "Participation aux élections municipales 2020 en métropole: l'effet du Covid-19." Project Attitudes Towards COVID-19 - A Comparative Study Note No. 10. June. https://www.sciencespo.fr/cevipof/attitudesoncovid19/publications/.

Collectif Degeyter. 2017. Sociologie de Lille. Paris: La Découverte.

Denny, K., and N. Doyle. 2007. "Analysing the Relationship Between Voter Turnout and Health in Ireland.” Irish Medical Journal 100 (8): 56-58.

Gerber, A. S., D. P. Green, and C. W. Larimer. 2008. "Social Pressure and Voter Turnout: Evidence from a Large-Scale Field Experiment.” American Political Science Review 33-48.

Gollust, S. E., and W. M. Rahn. 2015. "The Bodies Politic: Chronic Health Conditions and Voter Turnout in 2008 Elections." Journal of Health Politics, Policy and Law 40 (6): 1115-1155. doi:10$1215 / 03616878-3424450$.

Gombin, J. 2017. “spReapportion: Reapportion Data from One Geography to Another.”, R Package Version 0.1.0.9001. https://github.com/joelgombin/spReapportion.

Héran, F., and D. Rouault. 1995. "La double élection de 1995: exclusion sociale et stratégie d'abstention." Insee Première, No. 414. https://www.epsilon.insee.fr/ jspui/handle/1/10071. Jaffré, J. 2020. "L'abstention aux élections municipales depuis l'après-guerre (1947-2014)." Note Sciences Po/CEVIPOF. March. https://www.sciencespo.fr/cevipof/fr/ content/municipales-2020-lesnotes-de-recherches. 
Knack, S. 1994. "Does Rain Help the Republicans? Theory and Evidence on Turnout and the Vote." Public Choice 79: 187-209.

Leininger, A., and M. Schaub. 2020. "Voting at the Dawn of a Global Pandemic." Preprint, April. https://osf.io/preprints/socarxiv/a32r7/.

Lumley, T. 2017. "Pseudo-R2 Statistics Under Complex Sampling." Australian and New Zealand Journal of Statistics 59 (2): 187-194. doi:10.1111/anzs.12187.

Lumley, T. 2020. “Survey: Analysis of Complex Survey Samples”. R Package Version 4.0. https://cran.r-project.org/package=survey.

Mattila, M., P. Söderlund, H. Wass, and L. Rapeli. 2013. "Healthy Voting: The Effect of SelfReported Health on Turnout in 30 Countries." Electoral Studies 32 (4): 886- 891. doi:10.1016/j.electstud.2013.07.010.

Neihouser, M., C. Kelbel, and F. Briatte. 2020. "Élections municipales: ce que révèle l'analyse du premier tour de mars 2020." The Conversation, May 10. https:// theconversation.com/electionsmunicipales-ce-que-revele-lanalyse-du-premier-tour-de-mars-2020-136876.

Noury, A., A. François, O. Gergaud, and A. Garel. 2021. "How Does COVID-19 Affect Electoral Participation? Evidence from the French Municipal Elections.” Plos One 16 (2): e0247026. doi:10.1371/journal.pone.0247026.

Pacheco, J., and J. Fletcher. 2014. "Incorporating Health into Studies of Political Behavior." Political Research Quarterly 68 (1): 104-116. doi:10.1177/1065912914563548.

Persson, M., A. Sundell, and R. Ohrvall. 2014. "Does Election Day Weather Affect Voter Turnout? Evidence from Swedish Elections." Electoral Studies 33: 335-342. doi:10. 1016/j.electstud.2013.07.021.

Rebecq, A. 2019. "Icarus: An R Package for Calibration in Survey Sampling." R Package Version 0.2.0. https://cran.r-project.org/package=icarus.

Rivière, J., C. Colange C, M. Bussi, B. Cautrès, S. Freire-Diaz, and A. Jadot. 2014. "Studying Electoral Cleavages from the Intra-Regional to the Infra-Urban Scale. The Case of the 2010 Regional Election in Nord- Pas de Calais.” Territory in Movement Journal of Geography and Planning 16: 3-17.

Uhlaner, C. J. 1989. "Relational Goods and Participation: Incorporating Sociability into a Theory of Rational Action." Public Choice 62 (3): 253-285.

Zeitoun, J.-D., M. Faron, S. Manternach, J. Fourquet, M. Lavielle, and J. H. Lefèvre. 2020. "Reciprocal Association Between Participation to a National Election and the Epidemic Spread of COVID-19 in France: Nationwide Observational and Dynamic Modeling Study." medRxiv preprint, May. doi:10.1101/2020.05.14.20090100. 